\title{
The smoke emission properties of selected elements of furnishing apartments in the building
}

\author{
Marzena Półka ${ }^{1}$, Jan Białek ${ }^{2}$ \\ Faculty of Fire Safety Engineering, The Main School of Fire Service, Warsaw, Poland \\ E-mails: ${ }^{1}$ mpolka@sgsp.edu.pl; marzena.polka@gmail.com (corresponding author)
}

\begin{abstract}
The paper presents the results of tests for smoke optical density conducted on four various floor panels of building interior design. As regards safety, wood base or polymeric panels are flammable materials, and their ignitability and smoke generation depend to a large extent on its chemical composition, density and thickness of element. Smoke emission is one of basic elements that characterise the fire environment. Consequently the objective of the paper was to carry out a comparative analysis of smoke generation of chosen floor panels at selected thermal expositions and at the presence or absence of a stimulus igniting the volatile gaseous phase (pilot flame). For needs of experimental research use was made of: samples (oak board), wood-based materials (two type of HDF panels) and PVC floor panel. Experimental research has been carried out based on the standard PN ISO 5659 - 2:2013-06. The tests results were compared with international optical smoke density requirements for the interior design of ships and trains.
\end{abstract}

Keywords: smoke emission, fire safety engineering, floor panels.

\section{Introduction}

Wood is one of the most important natural resources used by man, and is primarily used in the construction industry, for the production of tools and arms. The development of technology and wood processing allowed introducing also wood-based materials into everyday use, which thanks to their more advantageous properties are better than classical wood (Tran, Thuy Nguyen, \& Lau, 2018; Menis, Fragiacomo, \& Clemente, 2019). As regards safety, wood or woodbase floor panels are flammable materials, and theirs ignitability and smoke generation depend to a large extent on its chemical composition, density and thickness of element (Babrauskas, 2001; Drysdale, 2011; Półka, Konecki, \& Polakovič, 2011; Kimmerle, 1974; Menis et al., 2019; Ukleja, Delichatsios, Delichatsios, \& Zhang, 2013). PVC panels has very good processing parameters. PVC, as a thermoplastic, under the influence of temperature, it softens and flows from here, it is also relatively easy to produce building elements. The distinguishing feature of PVC from other thermoplastics is also its susceptibility to modification in terms of the degree of plasticity. In tests on the degree of flammability of PVC window profiles, they are usually difficult to ignite, because during its combustion a charred layer is formed on the surface of the material hindering access of heat and oxygen to the deeper layers of the polymer. Additionally during decomposition and combustion PVC the hydrogen chloride is released, which as a non-flammable gas dilutes a flammable mixture of products.

Smoke emission is one of basic elements that characterise the fire environment. According to statistical data over $80 \%$ fatalities during fires are caused by hazards posed by smoke (Stec \& Hull, 2010). Limiting the visibility splay is one of the main hazards related to smoke release in fire conditions. Other important components are high tempera-ture, the ensuing thermal radiation and toxicity. A significant smoke emission takes place in conditions of oxygen shortages. In such conditions the combustion is incomplete or partial, and products of those transformations are main components of the smoke dispersed phase. As regards the group of polymer materials, the lowest smoke generation was recorded for example for wood, polypropylene and polyethylene, while a considerable intensity of smoke generation is usually ascertained for poly(vinyl chloride) or polystyrene (Purser, 2009). Smoke emission properties during the combustion process of floor panels is affected by several factors, starting with the type of material (chemical ingredients) up to the type of combustion. Dense smoke generated by burning materials hinders evacuation from buildings and extinguishing of the fire. Limited movement possibilities on an area comprised by a fire intensifies the feeling of imminent danger, impairs the body capacity and may even cause panic (Purser, 2009, Konecki, Półka, Tuśnio, \& Małozięć, 2012). It is considered that places with limited height and cubage, which are relatively quickly filled with smoke, in such a way affecting directly people present in them, are particularly danger-

(C) 2019 Authors. Published by VGTU Press. This is an open-access article distributed under the terms of the Creative Commons Attribution (http://creativecommons.org/licenses/by/4.0/) License, which permits unrestricted use, distribution, and reproduction in any medium, provided the original author and source are credited. 
ous. A characteristic feature of a fire is the generation of smoke, which hinders the execution of rescue and extinguishing actions. Intense dense smoke generated during combustion causes difficulties to rescuers in gaining access to the place where the fire has started and to victims in need of evacuation exerts a significant impact on changes of the surrounding environment.

Appropriate selection of the material for the interior finishing element of buildings depends primarily on aesthetic values, resistance to wear and tear and comfort of usage. As a consequence elements of building interior furnish-ings are mainly made of plastics, which easily undergo thermal decomposition at elevated temperatures, generating concurrently relatively large amounts of smoke. This hazard keeps intensifying due to ever growing application of polymer materials in the construction industry, as they constitute approximately $10-15 \%$ of the total mass of flam-mable materials in apartments. As a result of combustion of materials, including especially plastics, smoke is gener-ated, which comprises solid or liquid particles. The most frequent causes of rooms fires are leaks of easily flammable liquids, arson, defects of the electrical wiring and electronics, failures of the exhaust gas system, or failure of engine and fittings or ignition of sound-insulating materials (Janowska, Przygocki, \& Włochowicz, 2007; Półka, 2010; Półka, Konecki, \& Salamonowicz, 2010).

In this work an attempt has been made at determining smoke generating properties of interior floor panels with ref-erence made to obtained results of maritime and railway standards.

\section{Materials and method}

\section{Description of materials for testing}

For needs of experimental research use was made of: samples (oak board), wood-based materials (two type of HDF panels - AC3, AC5) and PVC floor panel. In accordance with the standard (PN-EN ISO 5669-2) samples sized $75 \times 75 \mathrm{~mm}$ were wrapped in aluminium foil and placed in a special grip with a washer made of fire resistant fibres to provide thermal insulation of the bottom part of the sample. Thickness of the sample was up to $12 \mathrm{~mm}$. Experimental research has been carried out based on the standard (ISO 5659 -2:2012). Table 1 presented the characteristics of the composition of the samples of floor panels for studies.

Table 1. Characteristics of the composition of the tested samples of floor panels

\begin{tabular}{|c|c|c|}
\hline Floor panels & The main composition & Characteristics \\
\hline $\begin{array}{l}\text { Oak board } \\
\text { panel }\end{array}$ & $\begin{array}{l}\text { Panel had a layered structure, and its top layer was made of } \\
\text { oak. The middle and bottom layers were made of hardwood, } \\
\text { while the upper layer, } 4.5 \mathrm{~mm} \text { thick, was made of oak. }\end{array}$ & The board tested was made of hardwood. \\
\hline $\begin{array}{c}\text { HDF panels - } \\
\text { AC3 }\end{array}$ & $\begin{array}{l}\text { Its bottom layer, i.e. the backbone layer, is made of cellulose } \\
\text { combined with polymeric resins. Above this layer there is a } \\
\text { wood-based panel with high density HDF. The density of the } \\
\text { HDF board is over } 850 \mathrm{~kg} / \mathrm{m}^{3} \text {. The top layer of the panel is a } \\
\text { laminate, (covered with a layer of resin). The AC3 floor panel } \\
\text { uses the CPL (Continuous Pressed Laminate). The last layer } \\
\text { of the AC3 panel was an overlay or mineral coating increasing } \\
\text { resistance to abrasion and scratches. }\end{array}$ & $\begin{array}{l}\text { Floor panel AC3 - has a layered structure and is } \\
\text { one of the most popular laminate panels used in } \\
\text { most Polish homes. The marking of the AC3 floor } \\
\text { panel depends on the overlay layer applied in it } \\
\text { and this is the so-called "abrasion class" of the } \\
\text { floor panel. The tested panel had the AC3 symbol, } \\
\text { which means that the panel has a 3rd class of } \\
\text { abrasion resistance in a 5-point scale according to } \\
\text { the standard (PN-EN 13329+A1:2017-12). }\end{array}$ \\
\hline $\begin{array}{c}\text { HDF panels - } \\
\text { AC5 }\end{array}$ & $\begin{array}{l}\text { The bottom layer of the panel is a cellulose layer combined } \\
\text { with polymeric resins. Above her is an HDF board. Above the } \\
\text { high density board there is a laminate in this case it is a lami- } \\
\text { nate obtained under high pressure - HPL (High Pressure } \\
\text { Laminate). The laminate consists of several layers of paper, } \\
\text { which is impregnated with resin. Inside the panel there are } \\
\text { sheets impregnated with phenolic resin, and on the outside } \\
\text { there are sheets of decorative paper impregnated with mela- } \\
\text { mine resin. The last layer of the overlay panel is more re- } \\
\text { sistant to abrasion and scratches compared to the AC3 panel - } \\
\text { it was AC5. }\end{array}$ & $\begin{array}{l}\text { Floor panel with a layered structure very similar } \\
\text { to the AC3 panel. This type of floor panel is more } \\
\text { resistant to physical factors than the AC } 3 \text { panel, } \\
\text { so it can be used in places with high traffic, for } \\
\text { example in public places. }\end{array}$ \\
\hline $\begin{array}{l}\text { PVC floor } \\
\text { panel }\end{array}$ & $\begin{array}{l}\text { Vinyl panels also have a layered structure: the center or core } \\
\text { of the panel is made of HDF, and the bottom and top layer is a } \\
\text { cork. This solution causes the floor to be quiet in use. There is } \\
\text { a vinyl coating on the top layer of the cork and this is the main } \\
\text { difference compared to laminated panels. The main advantage } \\
\text { of vinyl panels is their higher thermoplasticity and resistance } \\
\text { to mechanical damage. }\end{array}$ & $\begin{array}{l}\text { Its name comes from poly (vinyl chloride) and is a } \\
\text { synthetic polymer from the group of vinyl poly- } \\
\text { mers obtained as a result of polymerization of } \\
\text { vinyl chloride. }\end{array}$ \\
\hline
\end{tabular}




\section{Characteristic features of the research method}

To determine smoke generating properties of selected materials, the so-called single-chamber test was performed according to (ISO 5659-2:2017-08, 2017). Figure 1 presents the diagram of the research stand.

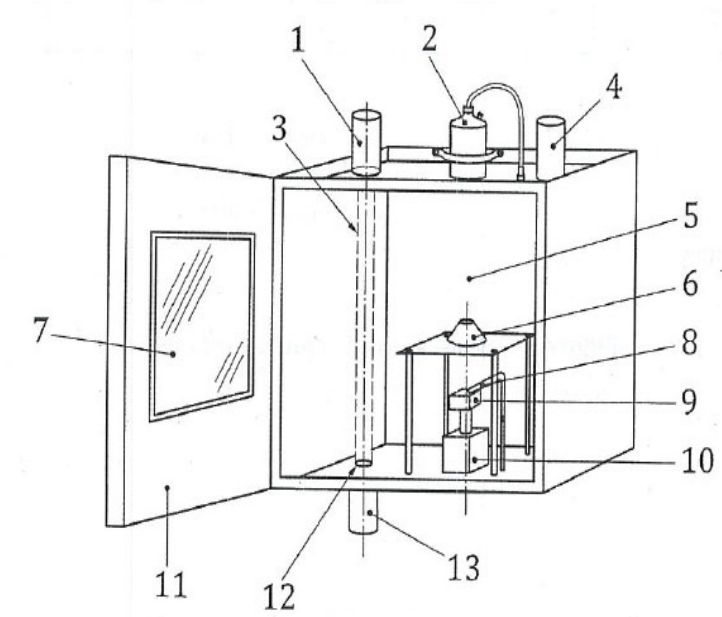

1. Optical measurement system,

2. Pressure controller,

3. Optical path,

4. Exhaust with shutters,

5. Smoke chamber,

6. Cone radiator,

7. Window

8. Pilot flame,

9. Specimen holder,

10. Scale,

11. Chamber front door,

12. Floor inspection viewer of optical system,

13. Light source.

Figure 1. Chamber for testing optical density of smoke (ISO 5659-2:2017-08)

The basic characteristic feature delimited based on conducted measurements was a change of specified optical density of smoke in the time function determined in accordance with the Eq. (1) (ISO 5659-2:2017-08):

$$
\mathrm{Ds}=\frac{\mathrm{V}_{\mathrm{k}}}{\mathrm{S} * \mathrm{~L}} \log \frac{T_{r o}}{T_{r}}=\frac{\mathrm{V}_{\mathrm{k}} * D}{\mathrm{~S} * \mathrm{~L}},
$$

where:

Ds - specified optical smoke density [-];

$\mathrm{V}_{\mathrm{k}}$ - volume of measurement smoke chamber $\left[\mathrm{m}^{3}\right]$;

$\mathrm{L}$ - thickness of smoke layer [m];

$\mathrm{S}$ - active surface of sample $\left[\mathrm{m}^{2}\right]$;

$T_{r o}-$ initial transmittance of light [\%];

$T_{r}$ - light transmittance [\%];

$D$ - optical density of smoke [-].

To allow executing a wider analysis, also recorded were such derivative values, as time until achievement of Ds_max, value of specific optical density after 4 minutes Ds_4 and area under curve of proper optical density during the first 4 minutes VOF_4. Once the maximum value of Dsmax has been achieved, the value of proper optical density decreased. This took place as a result of vanishing of smoke due to coagulation, sedimentation, evaporation and condensation on chamber walls.

The Dsmax values were used to determine requirements concerning smoke generating properties of materials and components used in railway industry according to standard (PN-EN 45545-2+A1:2015-12, 2015), and smoke generation of materials and products were determined by parameters given in standard (ISO 5659-2:2017-08). Method (ISO 5659-2:2017-08) is applied in maritime construction (International Code Part 2, 2012) and method (ISO 5659-2:2017-08) in railway construction, and the scope of parameters being delimited has been determined depending on the designation of test results. In railway construction standard is used in standard PN-EN 45545-2, which defines requirements with respect to smoke generation of materials used in railway vehicles, classified according to operating and design categories, designated for transporting passengers on European railway lines.

The following parameters are used for classification of materials:

-Ds_max - maximum specified optical density of smoke achieved during testing [-];

-Ds_4 - proper optical density of smoke after a time of 4 minutes [-];

- VOF4 - area under curve of proper optical density during the first 4 minutes [min].

The tests were performed in two configurations, i.e. with the use and without the use of a gas burner to ignite thermal decomposition products. The value of thermal radiation intensity flux as adopted at the level of $25 \mathrm{~kW} / \mathrm{m}^{2}$ and $50 \mathrm{~kW} / \mathrm{m}^{2}$ (without piloted ignition).

Figure 2 presents the view of the research smoke chamber. 

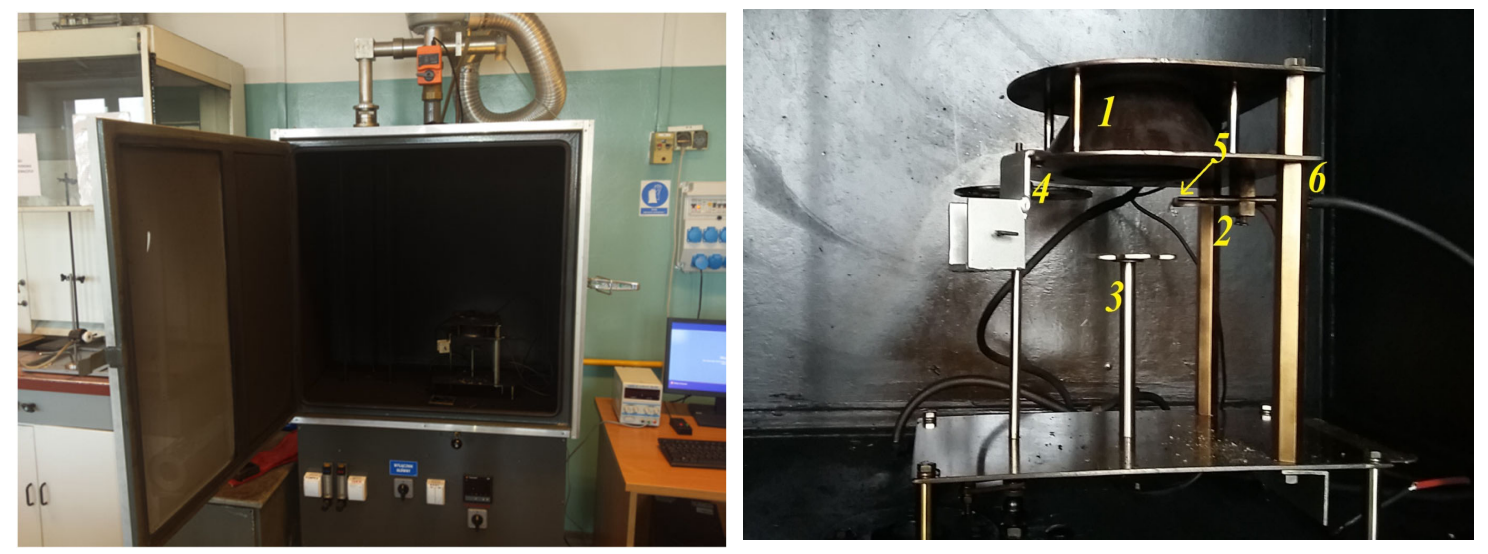

Figure 2. View of chamber and cone radiator for testing optical density of smoke: 1 - Cone radiator; 2 - Pilot burner; 3 - Base for fixing the sample; 4 - Shutter; 5 - Sparker; 6 - Gas valve

\section{Results and discussion}

Average values of three measurements of defined parameters were presented in Tables 2-4.

Table 2. Listing of average values of delimited parameters - tests at external heat flux $25 \mathrm{~kW} / \mathrm{m}^{2}$ without the presence of burner flame (Białek, 2018)

\begin{tabular}{|l|c|c|c|c|c|}
\hline Tested material & $\begin{array}{c}\text { Average time of } \\
\text { combustion start } \\
{[\mathrm{s}]}\end{array}$ & $\begin{array}{c}\text { Average } \\
\text { Ds_max [-] }\end{array}$ & $\begin{array}{c}\text { Average time until } \\
\text { achievement of } \\
\text { Ds_max [s] }\end{array}$ & $\begin{array}{c}\text { Average } \\
\text { Ds_4 [-] }\end{array}$ & $\begin{array}{c}\text { Average } \\
\text { VOF_4 [min] }\end{array}$ \\
\hline Oak board panel & no ignition - & 699.74 & 775 & 180.02 & 273.65 \\
\hline HDF panels - AC3 & -no ignition & 699.74 & 658 & 65.16 & 82.57 \\
\hline HDF panels - AC5 & no ignition & 699.74 & 883 & 52.25 & 71.61 \\
\hline PVC floor panel & no ignition & 699.74 & 353 & 355.44 & 559.02 \\
\hline
\end{tabular}

Table 3. Listing of average values of delimited parameters - tests at external heat flux $25 \mathrm{~kW} / \mathrm{m}^{2}$ in the presence of burner flame (Białek, 2018)

\begin{tabular}{|l|c|c|c|c|c|}
\hline Tested material & $\begin{array}{c}\text { Average time of } \\
\text { combustion start } \\
{[\mathrm{s}]}\end{array}$ & $\begin{array}{c}\text { Average } \\
\text { Ds_max [-] }\end{array}$ & $\begin{array}{c}\text { Average time until } \\
\text { achievement of } \\
\text { Ds_max [s] }\end{array}$ & $\begin{array}{c}\text { Average } \\
\text { Ds_4 [-] }\end{array}$ & $\begin{array}{c}\text { Average } \\
\text { VOF_4 [min] }\end{array}$ \\
\hline Oak board panel & 75 & 90.40 & 1200 & 45.16 & 105.81 \\
\hline HDF panels - AC3 & 48 & 112.86 & 705 & 9.43 & 18.20 \\
\hline HDF panels - AC5 & 186 & 116.50 & 1200 & 40.74 & 61.45 \\
\hline PVC floor panel & 54 & 348.10 & 555 & 234.77 & 464.35 \\
\hline
\end{tabular}

The amount of released smoke from the tested materials depends not only on the value of the thermal flux, but also on the presence of a pilot flame that burns the combustible gas phase and in this case we observe a smaller value of Ds_max. During combustion without the pilot flame, all tested samples reached the maximum value measured by the software used for testing, that is Ds_max 699.74 [-]. While during combustion with piloted flame the smallest value Ds max was reached by a floor board sample of $90.40[-]$ and it was lower by $380 \%$ than the value obtained for the PVC panel sample, which Ds, max in these test conditions was 348.10 [-].

Table 4. Listing of average values of delimited parameters - tests at external heat flux $50 \mathrm{~kW} / \mathrm{m}^{2}$ without the presence of burner flame (Białek, 2018)

\begin{tabular}{|c|l|c|c|c|c|c|}
\hline No. & Tested material & $\begin{array}{c}\text { Average time of } \\
\text { combustion start } \\
{[\mathrm{s}]}\end{array}$ & $\begin{array}{c}\text { Average } \\
\text { Ds_max [-] }\end{array}$ & $\begin{array}{c}\text { Average time until } \\
\text { achievement of } \\
\text { Ds_max [s] }\end{array}$ & $\begin{array}{c}\text { Average } \\
\text { Ds_4 [-] }\end{array}$ & $\begin{array}{c}\text { Average } \\
\text { VOF_4 [min] }\end{array}$ \\
\hline 1. & Oak board panel & no ignition & 699.74 & 602 & 218.57 & 254.89 \\
\hline 2. & HDF panels - AC3 & no ignition & 699.74 & 598 & 71.6 & 100.44 \\
\hline 3. & HDF panels - AC5 & no ignition & 699.74 & 970 & 54.58 & 74.05 \\
\hline 4. & PVC floor panel & no ignition & 699.74 & 365 & 354.72 & 536.08 \\
\hline
\end{tabular}


AC5 floor panel proved to be the best material from all the tested ones with respect to smoke generating properties, and its samples have offered the lowest value of optical density after 4 minutes for testing variants without the application of the pilot burner, with the flammable phase of decomposition products of this sample during the testing in which the burner was used to ignite at latest.

Coating of a panel by HPL exerts the most advantageous impact on the value of proper density and the ignition time of flammable gaseous phase, while materials covered by laminate of poly(vinyl chloride) have achieved the highest Ds, max values during testing without the presence of the pilot burner.

Ds_max value for samples tested for needs of this article (floor panels comprise predominantly fibreboard) equals to 699.74 [-] this is the maximum value that can be tested in this chamber. Those higher values obtained during the decomposition of samples of floor panels could be caused by the fact that apart from fibreboard their structure comprises other layers that are bound by glue. This could cause an increase in the Ds max value.

Ds_max values for sample of the vinyl panel during exposure to radiation with the value of $25 \mathrm{~kW} / \mathrm{m}^{2}$ (without the presence of the burner) were clearly the highest from among the studied materials (higher than floor board by $380 \%$, and this was the biggest difference). A review of data available from literature (Stec \& Hull, 2010) allows the presumption that poly(vinyl chloride) (used as laminate in that panel) has to a large extent contributed to such a high Ds_max value. This arises from the fact that conversely to cellulose products it has a higher value of maximum specified optical density during flame combustion than in flameless conditions.

\section{Conclusions}

The following conclusions may be drawn from results of conducted studies and from a review of data obtained from literature:

- Limitation of visibility by generated smoke depends not only on the thermal flux, but also on the presence of flame during combustion, which ignites the gaseous phase, and as a rule in such conditions the value of Ds_max becomes reduced.

- The thermal decomposition products of the AC5 floor panel ignited the latest at external heat flux $25 \mathrm{~kW} / \mathrm{m}^{2}$ in the presence of a pilot flame in comparison with others tested materials (ignition in $186 \mathrm{sec}-$ onds due to the HPL laminate layer on the panel that best protects it against thermal radiation). When the samples are exposed to the radiation of $25 \mathrm{~kW} / \mathrm{m}^{2}$ in the presence of pilot burner, the flammable gas phase obtained from the samples: AC3 panel, PVC and floor board ignited at 48, 54 and in 75 seconds. The time difference between the longest and the shortest ignition time is almost fourfold.

- A comparison of results obtained for the tested samples with the standard pertaining to railways has shown that floor panel class AC3 and floor panel class AC5 have met all levels of requirements for two sets of requirements, and that they may be used in practice in any part of the train as material for interior finishing. The advantageous categorisation of those materials for needs of interior finishing in trains is possible thanks to the fact that they have a low Ds_4 value. This arises from the fact that their top layer is covered by resistant laminate. Authors of the standard have considered the value of 4 minutes as a threshold, after which the train would stop, and the people present in it would manage to escape. On the other hand, the sample of floor board and vinyl panel are characterised by certain limitations in their usage as a finishing material in trains, because their samples have achieved a higher value of Ds_4.

- Attempts should be made to verify the obtained results by full-scale tests. $\bar{C}$ Conclusions or generalizations about your research should be presented.

\section{Acknowledgements}

This work was supported by the Polish National Centre for Research and Development (NCBiR) - Projects No DOB-BIO9/18/01/2018 "Conditions for access to buildings for vehicles of fire protection units, including new tech-nologies for carrying out rescue and fire-fighting operations”, 2018-2021.

\section{References}

Babrauskas, V. (2001). Ignition Handbook: Principles and application to fire safety engineering fire investigation, risk management and forensic science. Fire Science Pub.

Białek, J. (2018). Analiza dymotwórczości wybranych paneli podłogowych (Engineering diploma thesis). The Main School of Fire Service, Warsaw (in Polish).

Drysdale, D. (2011). An introduction to fire dynamics. John Wiley and Sons, NewYork. https://doi.org/10.1002/9781119975465

International Maritime Organization (IMO). (2012). International Code for the Application of Fire Test Procedures (2010 FTP Code) mandatory from 1 July 2012.

International Organization for Standartization. (2017). Plastics - Smoke generation - Part 2. Determination of optical density by a single - chamber test (ISO 5659-2:2017-08). 
Janowska, A., Przygocki, W., \& Włochowicz, A. (2007). Flammability of polymers and polymeric materials. WNT, Warsaw.

Kimmerle, G. (1974). Aspects and methodology for the evaluation of toxicological parameters during fire exposure. Journal of Fire and Flammability, 1(2), 7-23.

Konecki, M., Półka, M., Tuśnio, N., \& Małozięć, D. (2012). Effect of fire retarding agents for wood on the change of fire environment in room systems. Przemyst Chemiczny, 91(2), 167-172.

Menis, A., Fragiacomo, M., \& Clemente, I. (2019). Fire resistance of unprotected cross-laminated timber floor panels: Parametric study and simplified design. Fire Safety Journal, 107, 104-113. https://doi.org/10.1016/j.firesaf.2018.02.001

Polish Committee for Standardization. (2015). Railway applications - Fire protection on railway vehicles - Part 2 (PN-EN 45545-2+A1:2015-12).

Polish Committee for Standardization. (2017). Laminowane pokrycia podłogowe - Elementy z warstwa użytkowa na bazie aminoplastycznych termoutwardzalnych żywic - Specyfikacje, wymagania i metody badań (PN-EN 13329+A1:2017-12).

Półka, M. (2010). Toxicity analysis of thermal decomposition and combustion products obtained from selected epoxy materials. Safety \& Fire Technique, 3, 73-81.

Półka, M., Konecki, M., \& Polakovič, P. (2011). Analysis of the range of visibility in smoke from combustion of some polymeric materials. Przemyst Chemiczny, 90(8), 1567-1573.

Półka, M., Konecki, M., \& Salamonowicz, Z. (2010). Toxicity of the fire environment. Polish Review of Aviation Medicine, 4(16), 357-370.

Purser, D. A. (2009). Assessment of hazards to occupants from smoke. In Toxic Gases and Heat, The SFPE Handbook of Fire Protection Engineering (4 ${ }^{\text {th }}$ ed.). P. J. DiNeno (Ed.). National Fire Protection Association, Quincy, MA 02269.

Stec, A. A., \& Hull, T. R. (2010). Fire toxicity. Woodhead Publishing, CRC Press LLC, Cambridge. https://doi.org/10.1533/9781845698072

Tran, Ph., Thuy Nguyen, Q., \& Lau, K. T. (2018). Fire performance of polymer-based composites for maritime infrastructure. Composites Part B: Engineering, 155, 31-48. https://doi.org/10.1016/j.compositesb.2018.06.037

Ukleja, S., Delichatsios, M. A., Delichatsios, M. M., \& Zhang, J. (2013). Smoke concentrations inside and outside of a corridor-like enclosure. Fire Safety Journal, 60, 37-45. https://doi.org/10.1016/j.firesaf.2013.03.009 